\title{
Proměny postojů českých politických stran ke vztahu církví a státu $v$ průběhu 19. a 20. století1
}

\author{
The Changing Positions of Czech Political Parties towards \\ the Relationship between Church and State during \\ the 19th and 20th Centuries
}

\author{
Stanislav Balík, Otto Eibl
}

\begin{abstract}
Churches and religious organizations were always major actors in the public sphere in European history. The nature and intensity of the relationship between church and state found expression in the presence of significant political cleavage from the end of the 19th century onwards. The church-state cleavage helped to shape the structure and content of the dialogue among various political actors. Throughout Europe this dialogue continues today albeit with different content and dramatically lower intensity. It is no different in the Czech (Czechoslovak) environment. The aim of this article is to find out how the Czech political parties' positions towards the relationship between church and state changed during the 20th century (from the birth of modern political parties in the late 19th century until 2010). In order to reply to this question we analyse the relevant political parties' (electoral) manifestos. First, we identify the core values of the parties, and then we focus on identifying their (ideological) stances on the issue.
\end{abstract}

KEYWORDS political parties, state-church cleavage, secularisation

\section{Úvod}

Cílem tohoto článku je zodpovědět otázku, jak se měnily postoje politických stran působících na území dnešní České republiky ke vztahu církve a státu, a to od doby zrodu moderních politických stran až do roku 2010. Předmětem našeho zájmu jsou české politické strany v českých zemích; nezkoumáme tedy strany německé, slovenské, rusínské, mad'arské či polské, jakkoli byly ve zkoumaném období let 1860-2010 součástí stranických systémů v českých zemích (srv. Malír a Marek 2005), případně jakkoli byl český stranický systém subsystémem stranického systému jiného. Důležité pro nás nejsou proměny názvů či konkrétního organizačního ustrojení jednotlivých aktérů. O politických stranách v letech 1860-1948 uvažujeme z pozice jejich tzv. táborového charakteru a kontinuity, která byla přetržena právě až únorovými událostmi roku 1948. Bez dalšího vnitřního rozlišování tak pro nás jsou předmětem výzkumu období před rokem 1948 následující politické tábory: národně liberální (zahrnující

Sociálni studia. Katedra sociologie FSS MU, 3/2013. S. 107-131. ISSN 1214-813X.

1 Článek byl zpracován v rámci řešení grantového úkolu Český antiklerikalismus 1848-1948 (Grantová agentura ČR, P410/12/1435). 
i tzv. pokrokářský), sociálně demokratický, národně socialistický, agrární, katolický a po roce 1918 rovněž komunistický (k názvům a vývoji jednotlivých stran blíže viz například Balík, Hloušek, Holzer a Šedo 2003: 36-38, 68-76). Po roce 1989, vzhledem k tomu, že nedocházelo k proměnám jednotlivých relevantních stranických aktérů (ti, kteří získali zastoupení v dolní parlamentní komoře), se pak soustřed’ujeme na jednotlivé politické strany.

Téma článku je úzce spojeno s teorií štěpících linií (cleavages) zformulovanou Steinem Rokkanem (v českém prostředí srv. napríklad Hloušek a Kopeček 2004: 34-54). Pro naše potřeby je důležitá především linie stát vs. cirkev - produkt funkcionální dimenze procesů budování národa, kdy (v 16.-18. století) jednak v Evropě probíhaly velké spory mezi katolicismem a protestantismem, príípadně bylo možné zaznamenat velké úsilí absolutistických států omezit moc a vliv církví ve společnosti, respektive podř́ídit je státnímu dozoru. Tomu se církve a jejich př́slušníci bránili. V 19. a ve 20 . století se $\mathrm{k}$ těmto procesům přidal silný fenomén sekularizace. ${ }^{2}$ Ze všech těchto zdrojů mohl vzniknout silný rozpor mezi církví a státem, jehož produktem se stala existence explicitně katolických stran. České prostředí bylo do roku 1918 specifické tím, že struktury státu byly s katolickou církví, respektive katolicismem, identifikované (takže by teoreticky nemělo ke vzniku katolických stran dojít). Nicméně této skutečnosti již zcela neodpovídal stav společnosti, která (či přinejmenším její elity) byla (byly) stále více vůči katolicismu indiferentní. A právě z nesouladu těchto dvou skutečností vyplynula specifická česká situace.

Pro české prostředí a pochopení situace je důležité mít na vědomí, že z hlediska společenského modelu převládal před rokem 1918 v českých zemích konfesijní stát klasický, v době první a třetí republiky sekulární stát blížící se spíše odlukovému než kooperačnímu typu, po roce 1989 pak sekulární stát kooperační (Tretera 2002). Co se typologie dle způsobu úpravy vztahů státu a církve týče, převládal ve zkoumaném období typ nekonkordátní (konkordát platil pouze do roku 1870, kdy byl habsburským císařstvím vypovězen, dále od roku 1928 fakticky jen do roku 1938 platil Modus vivendi - jakási slabší forma konkordátu). Tyto proměny rámce, $v$ němž byly církevně-právní požadavky jednotlivých stran formulovány a jenž zde nemůže z prostorových důvodů být šiřreji představen, je nutné mít při čtení tohoto článku na zřeteli.

Poslední úvodní otázka budiž terminologická - přes vědomí výrazných rozdílů mezi institutem církve (církví) a náboženství bude těchto termínů užíváno synonymně. Důvod tkví ve skutečnosti, že takto $\mathrm{k}$ nim až na výjimky přistupovaly a přistupují i jednotlivé zkoumané

\footnotetext{
Ačkoliv předmět našeho výzkumu s otázkou sekularizace úzce souvisí, její teorii nemáme ambici představovat - odkazujeme zde na sociologické (viz např́klad Berger 1997; Nešpor a Lužný 2007; Vido 2011), filozofické (Gauchet 2004) či teologické (například Halík 2004) přístupy. Důležité pro nás jsou přirozeně i historiografické debaty o sekularizaci 19. a první poloviny 20. století (pro západoevropský kontext srv. McLeod 2008; pro český Fasora, Hanuš a Malír 2007 či 2009).

Podobně je tomu s typologií vztahu mezi státem a církvemi, jak ji představuje např́íklad R. Tretera (2002). Tzv. konfesně-právní systém lze členit jednak z hlediska společenského modelu (konfesijní stát - klasický a á rebours, sekulární stát - odlukový a kooperační) a jednak podle způsobu úpravy vztahů státu a církve (konkordátní a nekonkordátní) (srv. Krukowski 1998).
} 
programové dokumenty a jen obtížně lze odlišit, čeho (zda církve či náboženství) se konkrétní programové požadavky týkají.

\section{Politické programy jako zdroj pro určení postojů politických stran}

Postoje politických stran lze přirozeně měřit celou řadou způsobů. Pro formát tohoto textu jsme zvolili jeden z nich - kvalitativní obsahovou analýzu programových dokumentů relevantních politických stran. Při analýze se zaměříme zejména na identifikaci ideologických či hodnotových kořenů jednotlivých stran nebo na typy otázek (či problémů), které strany považovaly ve vztahu k církvím za důležité, a na jejich řešení. Pozornost budeme ale věnovat i rozsahu a prostoru, který strany těmto otázkám ve svých programových dokumentech věnovaly. Zkoumat tak budeme $\mathrm{v}$ první řadě obsah navrhovaných politických opatření a nepř́mo také důležitost, kterou jednotlivé strany kapitolám o vztahu církví a státu věnovaly. Cílem textu je pak podrobně popsat, jak v dané době relevantní politické strany reflektovaly církevní otázky ve svých programech a jak se tato jejich reflexe vyvíjela.

Jsme si dobře vědomi toho, že zachycujeme pouze výseč skutečnosti. Politická programatika není natolik dynamická, aby dokázala reagovat na okamžité podněty vyvstávající v průběhu předvolební kampaně. Ačkoli např́íklad národně-socialistická strana ve svých programových dokumentech před rokem 1914 církevní problematiku příliš neřeší (viz níže), volební kampaně jejích kandidátů byly postaveny na ostrém vymezení se vůči vlivu církví ve školách (srv. např́ílad Marek 2003: 526-529). Přesto jsme přesvědčeni, že analýza politických programů může jak vytvořit obraz dynamicky se měnících vztahů mezi různými politickými aktéry, tak vést ke vzniku zajímavé sondy „důležitosti“ otázek spojovaných $\mathrm{s}$ církvemi v rámci jednotlivých dějinných etap vývoje obsahu politiky na území dnešní České republiky (popř́ípadě bývalého Československa).

Vzhledem k odlišnému způsobu práce s programy politických stran ve dvou hlavních sledovaných periodách (do roku 1948 a po roce 1989) musíme rovněž zvolit dva odlišné způsoby výběru programových dokumentů. Logika výběru do analýzy zařazených programových dokumentů také odráží způsob, jakým byla a je utvářena politická veřejnost, respektive podle jakých klíčủ voliči hlasovali a hlasují pro konkrétní politickou stranu. Zatímco na konci 19. a na začátku 20. století byla volba z velké části předurčena sociálním postavením každého jednoho voliče, respektive jeho př́slušností k určité sociální skupině, na konci století 20. již sociální aspekt volby není tak silný a do voličova rozhodování vstupují spíše krátkodobé faktory. Mezi ty patří např́íklad aktuální témata, která jsou v politickém systému diskutovaná, volební kampaň, emoce, vztah k jednotlivým kandidátům atd. Není sice možné tvrdit, že strukturální proměnné (trrída, náboženství) z volebního chování zcela vymizely, jejich explanatorní síla ale drasticky klesla (Kopeček 2005; Rokkan a Lipset 1967; Thomassen 2005; Dalton 2008; Eibl 2011). To vedlo k oslabení vazeb mezi voliči a tradičními politickými aktéry (již nebyli schopni držet monopol na reprezentaci zájmů konkrétní skupiny voličů) a logicky i ke zvýšení soutěživosti stranických systémů (srv. Blumler a Kavanagh 1999; Hallin a Mancini 2004; Swanson 2004; Mazzoleni a Schulz 1999). Swanson (2008: 48) v této souvislosti tvrdí, že politika „víry a spásy“ byla nahrazena politikou „názoru a pragmatismu“. 
Tato skutečnost se odráží i v nezbytnosti toho, aby se po roce 1989 každá politická strana aspirující na parlamentní zastoupení prezentovala před každými volbami svým aktuálním (a aktualizovaným) předvolebním programem. To nám dává možnost v pravidelných intervalech sledovat proměny politické programatiky, čehož v příslušné pasáži využíváme. Nicméně pro období před rokem 1945 nic takového ,zvykem“ nebylo - předvolební program byl výjimkou. Proto zde vycházíme z analýzy programových dokumentů o síle programu základního či politického, tedy něčeho, co české politické strany přijaly během krátké doby po roce 1989, nicméně s postupem doby se od nich jak v praktické, tak i předvolební programatické rovině odchylovaly.

Ačkoliv text pracuje s odlišnými typy programových dokumentů, jejich obsahová analýza přináší srovnatelné výsledky. S ohledem na dobu vzniku jednotlivých dokumentů a výše stručně nastíněného mechanismu volebního chování plnily programy velmi podobné funkce (pro plný rejstř́k a podrobný popis funkcí stranických programových dokumentů viz Mareš a Fiala 1998): Poskytovaly voličům orientaci v politickém prostoru, pomáhaly jim při rozhodování (nebo je alespoň mobilizovaly), a to i prostřednictvím vymezení se vůči politickým konkurentům, a konečně poskytovaly nástroj, který umožňoval integrovat členy stran. Jak programy striktně volební, tak dlouhodobější programové dokumenty tak zastávají funkci propagační, profilační, agitační i operační (Mareš a Fiala 1998: 8). Data, která z jejich analýzy získáme, jsou tedy symetrická a snadno porovnatelná.

\section{Před rokem 1918}

Problematika úlohy náboženství ve veřejném prostoru a otázka církví a jejich vztahu ke státu pronikala do politického boje (a tedy i politických programů) jen pozvolna. V Programu Národních listů z roku 1860 nalezneme požadavek svobody náboženského vyznání, svobody církve a nezávislosti její vnitřní správy na státu. Představitelé Národní strany (tedy pozdějším termínem staročechů) se jasně distancovali od zasahování do otázek náboženských, respektive prrímo dogmatických, nebot' tyto „nejsou naším oborem, i hodláme se jich vystř́hati“. Přes tyto deklarace ale již zde nalezneme náznak vůle politiky vstupovat na náboženskou půdu: „Očekáváme, [...] aby církev naše dle obrazu prvotního křest’anstva a v duchu staré národní církve naší oživila zákonní své zř́zení synodální" (Program Národních listů, 20. 12. 1860, citováno podle Cibulka 2000: 46). To bylo vše (lze říct, že šlo o jediný, dále neopakovaný názor), $\mathrm{v}$ dalších programových dokumentech v té době ani jediná česká politická strana otázku církví neřeší. Až v roce 1891 přichází v programu Národní strany ocenění mravní úlohy náboženství. Stát se má postarat, aby „kněžstvu byla zajištěna slušnější existence z prostředků státních“ (Provolání Národní strany k volbám do ř́šské rady, 15. 2. 1891, citováno podle Cibulka 2000: 322).

Postupná změna přichází s nástupem Národní strany svobodomyslné (mladočechů) do politického boje. Ve svém programu z konce roku 1874 se mladočeši přihlásili k zásadě svobody svědomí a rovného práva všech náboženských vyznání (Program Národní strany svobodomyslné, 27. 12. 1874, citováno podle Cibulka 2000: 214). Ve svém prohlášení k zemským volbám 1874 kritizují ultramontánní proud v české společnosti (církvi) jakožto nehodný „Husova národa“. Zastánci ultramontanismu prý jeví „živější interes pro zájmy zpátečnické 
a cizé, než pro zájmy a potřeby samého národa“ (Mladočeské prohlášení $k$ volbám do českého zemského sněmu, 24. 6. 1874, citováno podle Cibulka 2000: 206). Vymezování se proti ultramontanismu sloužilo mladočechům k vymezení se vůči staročechům, kteří se snažili udržovat korektní vztahy s katolickými kruhy. ${ }^{3}$ Toto tvrzení lze doložit i rezolucí V. sjezdu mladočechů z roku 1889, kdy po patnácti letech interpretovali svi̊j vznik jakožto reakci na přibližování se staročechů klerikálním kruhům - staročeši se prý stali „na úkor dějepisných podání našeho národa vlastně jen přeochotnými podporovateli všelikých, za jich pomoci v poslední době zvláště povážlivě vzmáhajících se snah klerikálních a zpátečnických, jakož zejména při otázkách školských, při obmezení selského majetku atd." (Resoluce V. valného sjezdu Národni strany svobodomyslné k zemským volbám, 16. 6. 1889, citováno podle Cibulka 2000: 285). Mladočeši na konci 80 . let 19. století deklarovali, že budou odporovat každému pokusu o návrat škol do správy církevních úruadů. Dále a podrobněji otázku církví neřešili. Nicméně $\mathrm{z}$ jejich prostředí vyvstaly strany, které toto téma $\mathrm{v}$ dalších letech výrazně rozvinuly.

Nejradikálnější byly v tomto směru tzv. pokrokáršké strany ${ }^{4} \mathrm{Již} \mathrm{na} \mathrm{svém} \mathrm{prvním} \mathrm{sjezdu}$ se Strana pokrokových socialistů v roce 1896 ostře opřela do privilegované pozice katolické či jiné církve ve školách:

Ve věcech, které týkají se přesvědčení člověka o jeho poměru ku všehomíru a $\mathrm{k}$ božství, nemá býti již dítěti ve školách diktováno, co má věrit a má-li vůbec věrit. [...] Pokládáme náboženství za osobní věc jednotlivcovu, do které škola nemá práva ani dost málo mluviti. Nadržování některé církvi stojí v rozhodném odporu se svobodou svědomí. Žádáme tedy vyloučení církve ze škol. Též jsme odpůrci jakýchkoli podpor se strany státu neb obce pro náboženské ústavy neb společnosti, nebot' máme zato, že je nespravedlivo, z daní, placených veškerým občanstvem, udíleti dary institucím, s nimiž tito bud' většinou aneb menšinou nesouhlasí. Chce-li dělnictvo domu ku svému účelu, koupí si ho z vlastních peněz, a totéž měřítko má býti uznáváno i u těch, kdož chtí kostel, také jen ku svému modlení a kázání. Oddělením církve od státu dosáhněme též toho, že vlády nebudou moci tak často zneužíti i náboženství ku svým otrockým a panovačným choutkám. (Program strany pokrokových socialistů, 1896, citováno podle Harna a Kučera 2010: 37)

Méně obsáhle, obsahově však totožně, se vyjádřila o rok později Česká strana radikálně pokroková, když žádala oddělení církví od státu ,a vybavení školství ze všelikého jejich vlivu, jakož i zbavení ho každého rysu konfesijního, tudíž i vypuštění z něho vyučování náboženství“ (Program strany radikálně pokrokové. Usnesení prvního sjezdu strany, 4. 4. 1897, citováno podle Harna a Kučera 2010: 51). O tři roky později ve školském programu strana své stanovisko upřesnila - vyučování náboženství ve škole se může dít nanejvýš soukromě „ve srozumění s rodiči a správou školy v hodinách mimořádných“. Namísto náboženství se

3 Srv. redakční poznámka pod čarou č. 2, Doplnění programu Národní strany svobodomyslné, 7. 11. 1875, citováno podle Cibulka 2000: 224.

4 Šlo o značně proměnlivý konglomerát. Stavěly se do opozice jak vůči vídeňské vládě, tak vůči mladočechům jakožto př́liš konzervativnímu politickému subjektu. Zahrnout sem můžeme přinejmenším Českou stranu lidovou (realistickou), později působící pod názvem Česká strana pokroková (realistická), dále Stranu pokrokových socialistů, Českou stranu radikálně pokrokovou, Českou stranu státoprávní, Moravskou stranu pokrokovou (blíže srv. Harna a Kučera 2010: 11-24). 
řádným předmětem měla stát mravouka (etika) (Školský program strany radiálně pokrokové, 1900, citováno podle Harna a Kučera 2010: 68).

Odstranění vlivu klerikalismu ze škol si na druhém sjezdu v roce 1899 dala za cíl také Česká strana státoprávní. Náboženství bylo pro stranu čistě soukromou věcí jednotlivce bez vlivu na jeho práva a postavení ve veřejném životě. Výuka náboženství nemá mít místo ve škole, její financování má být plně v režii patřičné církve. Ačkoli vnitřní uspořádání církve mělo být podle státoprávní strany věcí církevní samosprávy, deklarovala strana, že „,chtějíce přirozeným právům jazyka svého průchod zjednati, jakož i důvodům rozumné účelnosti přihližejíce, považujeme zavedení jazyka národního do života církevního za nutné“. Stejně tak chtěla účinně podporovat „snahy po zrušení kněžského bezženství, jakož i klášternictví“ (Program strany státoprávní, 19. 2. 1899, citováno podle Harna a Kučera 2010: 85).

Pro volby v roce 1907 vydaly Česká strana státoprávní, Strana radikálně pokroková a Česká strana národně sociální „Jednotný pokrokový a demokratický program národní“. Jedna jeho pasáž se věnovala boji s klerikalismem - definovaným jako „pokrytectví a zneužívání citu náboženského k účelům světským“. Veřejně je

žalováno, že v národě se slavnou minulostí husitskou rozšiřuje se klerikalismus a zakotvuje se dnes stále mocněji a zasahá zcela po způsobu politických stran i do těchto voleb, zneužívaje k tomu kazatelny; hlásaje pravou občanskou válku proti úsilím o svobodnou školu, o reformu práva manželského a o oddělení církve od státu. (Co chce česká státoprávní demokracie, 1907, citováno podle Harna a Kučera 2010: 88-89)

Zajímavý je dobový náhled na řešení chudinské otázky, který nedává žádný prostor pro občanskou iniciativu či pro církevní charity - „chudinství budiž obstaráváno za součinnosti obce, země i státu“ (Program Moravské strany pokrokové, 1907, citováno podle Harna a Kučera 2010: 113).

Na ustavujícím - slučovacím - sjezdu České strany pokrokové (realistické) v roce 1905 byl přijat obsáhlý návrh programových zásad, který celý jeden oddíl věnoval programu církevně-politickému. Vedle výše zmiňovaných požadavků tu nově zaznívá návrh, aby se namísto náboženství ve školách vyučovala etika spolu s dějinami náboženství a jednotlivých vyznání. Učiteli se mohli stát jen „světské (laické) síly“ - tedy nikoli řeholníci či kněží. Civilní sňatek má být obligatorní, církevní oddavky smějí proběhnout až po civilním obřadu. Hřbitovy mají být výhradně obecní, církvím mají být odebrány matriky, církevní rády a kongregace měly být postaveny pouze pod spolčovací a shromažd'ovací zákon. Každá církev si měla veškeré své potřeby hradit výhradně ze svého, přičemž na jednotlivé náboženské obce měly kompletně přjít práva a povinnosti patronátů (Návrh programových zásad České strany pokrokové [realistické], 16. 5. 1907, citováno podle Harna a Kučera 2010: 160-161).

V dalších letech do první světové války se zmíněné požadavky vesměs opakovaly zvláště volání po odstranění vlivu církví na školy. Posun zaznamenal program České strany pokrokové (realistické) v roce 1912, kdy žádal, aby správa církví byla vyňata z ministerstva vyučování a byla předána ministerstvu vnitra. Tentýž programový dokument otevírá otázku pohřbívání „ohněm“ - „větší města zřizujtež krematoria, jakmile spalování mrtvol bude v Rakousku připuštěno“ (Program České strany pokrokové [realistické], 6.-7. 1. 1912, 
citováno podle Harna a Kučera 2010: 191, 208, 218). Jakkoli se v programech ve vztahu k církevní oblasti používal vesměs plurál - „církve“ -, bylo evidentní, že dominantní část programatiky mírí na církev největší, katolickou. Patrné je to z jedné formulace z roku 1907: „Výsady církví, zejména katolické, bud’tež zrušeny“ (Program České strany pokrokové, 1907, citováno podle Harna a Kučera 2010: 164).

Sociální demokraté tematiku vztahu církve a státu v prvních desetiletích své existence př́liš neřešili. $V$ jejich programových dokumentech se opakuje téměř výhradně pouze stručný požadavek oddělení církve od státu a školy od církve (Politický program, 7. 4. 1878, citováno podle Prokš 1998: 21). K tomu se v 80 . letech 19. století přidává požadavek, aby bylo náboženství prohlášeno za věc soukromou (Politický program, 25.-26. 12. 1887, citováno podle Prokš 1998: 27). Poslední významná inovace v oblasti sociálně demokratických náhledů na církevní otázku přišla na začátku 20. století, kdy byla obecní zastupitelstva vyzvána, aby se zdržela jakéhokoli subvencování nebo podporování staveb a podniků sloužících některé církvi (Politické rezoluce, 8.-10. 9. 1900, citováno podle Prokš 1998: 55).

Při založení národně sociální strany v roce 1897 stála v popředí jejího zájmu jiná témata nežli řešení církevní otázky - soustřed’ovala se především na odlišení se od sociální demokracie. V prvním (tzv. Klofáčově) programu z roku 1898 se strana hlásí k úplné svobodě těch náboženství, jejichž morálka je prodchnuta altruismem a sociálním duchem. Obstarávání náboženských funkcí mělo být hrazeno státem - o odluce tedy ještě ani slovo. Program oceňuje význam křest’anství, které však již staví do opozita vůči „prázdnému formalistnímu církevnictví“. V některých společenských otázkách byla strana jednoznačně konzervativní a měla tak společné názory s křest’anskými církvemi své doby - chtěla potírat prostituci odstraňováním jejích prríčin, preventivně (i represivně) vystupovat proti alkoholismu, odmítala bez výjimky konkubináty a požadovala zákonné stíhání frivolní a schválné nudity („oplzlé“ obrázky apod.) (První program národně-sociální strany, 1897, citováno podle Harna 1998: 36-39). O tom, že svoboda církví a náboženství má mít jisté meze, svědčí stranická podpora všem snahám po „zdemokratisování a zmodernisování stávajících církvi“", nebot' v tom vidí strana pokrok a prospěch „pro myšlénku demokratickou a tím i národ“ (Rezoluce k taktice, 11. 4. 1900, citováno podle Harna 1998: 44). Národní socialisté se snažili ostře vymezovat proti klerikalismu, který definovali jako politické zneuživání čistého křest’anského náboženství. Chtěli zůstat dobrými křest’any, a přitom potírat „hydru klerikalismu“ (K revizi prvního programu národně sociální strany, 1. 6. 1902, citováno podle Harna 1998: 62). Církve chtěli podř́dit „autoritě společenského zákonodárství, v němž pak nesmějí míti církve nijakých privilegií“ (Program České strany národně sociální, 28. 9. 1902, citováno podle Harna 1998: 65).

Alespoň minimální vstř́ícnost, kterou projevovali národní socialisté vůči katolíkům, respektive křestanům, vůbec neplatila vůči židům: „Běda proletariátu, svěří-li své vedení bezmyšlenkovitě židovstvu.“"Vinili židy ze sobeckosti, k níž jej vychovalo jejich náboženství. A přesto, že prý židé s prací již jen obchodují a jsou reprezentanty „,vysavačského kapitálu“ (burzy, banky, kartely), osvojili si i „vůdcovství sociální demokracie“ (Proč jsme národními socialisty, 1900, citováno podle Harna 1998: 58). Touto průhlednou konstrukcí hrající na nejnižší antisemitské pudy dělnických vrstev se snažili vymezit vůči svému konkurentu na levici. Paradoxní je, že téměř souběžně byli schopni deklarovat, že zavrhují náboženský antisemitismus (Program České strany národně sociální, 28. 9. 1902, citováno podle Harna 1998: 65). 
V programových dokumentech prvních dvaceti let existence strany stojí církevní problematika víceméně na okraji, národní socialisté vlastně vůbec neřeší to, co ostatní - vztah školy a církve, výuku náboženství apod. K výraznému zlomu dochází na samotném konci první světové války, kdy strana príijala - spolu se změnou názvu na Českou stranu socialistickou - na VIII. sjezdu na přelomu března a dubna 1918 nový program. Předznamenává tím již plně svou prvorepublikovou programovou identitu. Proto bude jeho analýza součástí následující kapitoly.

Agrárníci, jakkoli vzešli z mladočeského organizačního a ideového podhoubí, se v otázkách nábožensko-politických před rokem 1918 př́liš výrazně neprofilovali (jakkoli se postupně stávali reprezentanty ,pokrokové“ části venkovského nesocialistického obyvatelstva). V programu České strany agrární z roku 1903 se nachází pasáž oslavující husitské hnutí (Program České strany agrární, 18. 1. 1903, citováno podle Harna a Lacina 2007: 45-46) - což se v té době rovnalo otevřené deklaraci protikatolických pozic. Mezi agrárnické požadavky patřila svobodná škola, prostá ,pout všech, [...] nesloužící ničemu a nikomu“ (Program České strany agrární, 18. 1. 1903, citováno podle Harna a Lacina 2007: 58). Není zde ale otevřeně zmíněna církev či náboženství - oproti výše zmiňovaným stranám. O rok později dokonce v programu moravských a slezských agrárníků dochází ocenění úloha kněze ve vyučování: „Ve vyučování náboženství budiž největší váha kladena na mravovědu - v tom směru kněz s učitelem mají vděčné pole před sebou“ (Program České strany agrární pro Moravu a Slezsko, 11. 12. 1904, citováno podle Harna a Lacina 2007: 74). Vůči katolickým politickým stranám se vymezovali opatrněji: „Otázku náboženskou nechceme vtahovati do stavovské organisace. [...] Pravá, uprímná zbožnost, která nemusí hledat veřejnosti, je nám zajisté věcí nedotknutelnou a svatou - ale politické agitace s otázkami svědomí neuznáváme“ (Program České strany agrární pro Moravu a Slezsko, 11. 12. 1904, citováno podle Harna a Lacina 2007: 84).

Programatika katolických stran v otázce společenského postavení církví a náboženství měla nejenom za první republiky (i když tehdy skutečně výrazně), ale již před rokem 1918 výrazně reakční charakter, kdy př́iliš nevznášela vlastní požadavky, ale odporovala požadavkům většiny ostatních politických subjektů. Tak se již v později legendárním prvním programovém dokumentu českého politického katolicismu, v programu Křestansko-sociální strany v Čechách přijatém na sjezdu v Litomyšli v roce 1894, vyslovila ,proti bezkonfesionelnosti školy a nevěrecko-liberálnímu zákonodárství a žádá, aby školy byly v zásadě náboženskými a veškeré zákonodárství aby se dálo $\mathrm{v}$ souhlasu s pravdami náboženství křest'anského“ (Program Křest’ansko-sociální strany v Čechách, 1894, citováno podle Marek 2011: 41). Katolická strana národní na Moravě při svém vzniku v roce 1896 oceňovala, že největší část učitelstva je přesvědčena o důležitosti náboženského momentu ve výchově, nechtěla však tuto otázku nechat na dobré vůli jednotlivců, „,a proto domáhati se musíme vším úsilím uzákonění školy náboženské“ (Programové cíle Katolické strany národní na Moravě, 1896, citováno podle Marek 2011: 50).

Katolické strany si nicméně již $\mathrm{v}$ té době začínaly uvědomovat, že formální znaky nestačí. Tak sice žádaly alespoň čtyři hodiny týdně výuky náboženství, ale rovněž aby i ostatní učivo bylo prodchnuto náboženským duchem, 
aby mládež o mravní a kulturní důležitosti učení Kristova byla přesvědčena, aby nevycházeli ze školy žáci, kteří sice o Kristu slyšeli, ale jeho ctnosti, které kázal a konal, znáti a osvojiti se nenaučili, jako sebezapírání, lásku k bližnímu, poslušnost, pokoru a spravedlnost. (Program české strany křest’ansko-sociální, tzv. Vrbưv, 1897, citováno podle Marek 2011: 65)

Křest'anské a židovské děti měly navštěvovat své vlastní školy, učit je směl jen učitel shodného vyznání, který i svým životem a působením dává prríklad křest’ana. „Dle toho budiž výchova učitelů na ústavech učitelských přeměněna na základech křest’anských. [...] V záležitostech náboženských budiž podřízena škola kostelu“ (tamtéž: 65).

Katolické strany se vymezovaly především vůči liberalismu:

Na poli náboženském liberalismus rozséval nevěru a podrývaje svrchovanou autoritu Boha, podrýval tím i hlavní oporu mravnosti a kázně. Rozmáhající se náboženská netečnost a lhostejnost $\mathrm{k}$ nejsvětějším ideálům, šiřící se zneuznávání každé autority a bující nevázanost mravů a nekázeň jest hořkým ovocem této neblahé setby liberalismu. (Provoláni Křest'ansko-sociálni strany v Čechách, 1897, citováno podle Marek 2011: 72-73)

Útočili i na sociální demokracii jakožto „dceru“ a budoucí dědičku liberalismu, když připomíná prohlášení První internacionály z roku 1874, že jejím cílem je „vyhnati Boha ze svědomí a ze společnosti lidské“" (tamtéž: 72-73).

V dalších letech se vesměs opakovaly následující požadavky: katolický duch školy (doplněný odporem proti možnosti zrušení výuky náboženství), křest'anstvím prodchnuté zákonodárství, odpor proti liberalismu, proti soukromé povaze náboženství. Občas byly dále rozvíjeny - viz kupř́kladu návrh, aby náboženství bylo povinným předmětem nejen na obecných a středních školách, ale i na odborných (Program Strany katolického lidu v Čechách, 1906, citováno podle Marek 2011: 101), aby Koruna svatováclavská „opět zazáŕila v plném lesku svém na hlavě církevně pomazaného a korunovaného panovníka“" (Provolání výkonného výboru Katolické strany národní na Moravě, 18. 12. 1900, citováno podle Marek 2011: $95)$ atd. V časové shodě se zavedením všeobecného volebního práva pro muže v roce 1907 se v katolických programových dokumentech začíná objevovat odpor proti možnosti rozlučitelnosti katolického manželství.

Některé programové požadavky byly oborově značně specifické - tak kupř́íkladu katoličtí horníci a hutníci v roce 1895 žádali, ,aby účastenství při modlitbách před šichtou bylo pro všechny dělníky závazným“. Katolické strany (podobně jako socialistické) poměrně silně řešily otázku nedělního a svátečního klidu - ovšem z hlediska náboženského. V dolech měl být zaveden i sváteční klid (vedle nedělního) v délce přinejmenším 24 hodin, „, době příznivé domáhati se budeme klidu šestatřicetihodinového, jaký již v některých dolech jest zaveden“ (Program katolických horniků a hutniků, 1895, citováno podle Marek 2011: 44-45).

\section{První republika}

Situace ve vztahu mezi státem a církví se se vznikem samostatného Československa radikálně proměnila. Jedním z ideových piliřů, na nichž tzv. první československá republika stála, byl sekulární charakter státu a požadavek církevní odluky. Logicky se tak zcela proměnily i akcenty politických stran $\mathrm{v}$ této oblasti. 
Faktickým (nikoli právním) nástupcem pokrokářských stran za první republiky nebyla národní demokracie, ale jednak národní socialisté (viz níže), jednak voličskou podporou sice marginální, zázemím elit ale nikoli marginální Národní strana práce (vznikla roku 1925, sama se ve svém programu definovala jako „pokroková“). Přestože parlamentní zastoupení nezískala, soustřed'ovala vlivné osoby především z mocenského okruhu tzv. Hradu F. Peroutku, J. a K. Čapkovy a další. Ve svém programu z roku 1925 stále ještě vedla boj za odcírkevnění školství (Politický program Národní strany práce 1925: 5) - tedy bitvu přinejmenším v českých zemích již několik let vyhranou. Ostatně velká část jejího „,kulturního“ programu působí, jako by pocházela z předchozího období. Horovala za úplnou rozluku církví a státu, kterou však poměrně znejasňovala souběžným požadavkem garance svrchovanosti státní. Církve nemají být vůbec podporovány z veřejných prostředků. Zřrejmě usilovala i o zákaz katolických politických stran:

Náboženství nebudiž zneužíváno k politickým cílům. Rovněž i organisace osob nábožensky stejně smýšlejících musí nabýti rázu nepolitického. [...] Proto bude úkolem Národní strany práce, aby nesmlouvavou politikou protiklerikální čelila klerikálním snahám církevním i stranickým a aby poučila občanstvo - zvláště na Slovensku -, že rozluka církví od státu není aktem nepřátelství vůči náboženství, nýbrž výsledkem snah uplatniti důsledně státní svrchovanost a navrátiti církve od světské moci k pravému jejich poslání. (Politický program Národní strany práce 1925: 6-7)

Na Slovensku usilovala strana o zestátnění církevního školství, nebot’ církevní škola je „překážkou volného rozvoje výchovy“ (tamtéž: 17). Církevní otázka nebyla v programu zcela dominantní, nicméně ani okrajovou záležitostí.

Jak jsme se již zmínili, prvorepublikový programový vývoj národních socialistů byl předznamenán již na jaře 1918. V tehdy přijatém novém programu zaujímala náboženská otázka významnější místo než v programech předchozích. Český socialismus je stavěn do vývojové souvislosti s „,nábožensko-sociálním hnutím doby husitské“; tedy je představena později rozšířená figura, že český socialismus je pravým plodem křest’anství - oproti církvím tehdejší doby. V tomto programu se národní socialisté přidali k požadavkům většiny politických proudů své doby - odcírkevnění školy. Školské vyučování má být prodchnuto duchem vědecké pravdy a klást mravnost nad náboženství. Škola musí být nekonfesijní, náboženství jako vyučovací předmět musí být odstraněno ze škol. Církve už strana pojímá optikou běžných zájmových skupin, nesmí se ztotožňovat se státem, proto je nemožná forma církve státní (to je formulováno ještě v éře Rakousko-Uherska). Současně se ale strana stavěla za zásadu náboženské snášenlivosti a volnosti ve všech projevech veřejného života.

Konkrétnější byl požadavek, aby byla církevním orgánům odňata státní funkce vedení matrik a uzavírání sňatků. Nedělní a sváteční klid by neměl být odvozen od křest’anského svěcení neděle a svátků, stát by neměl být oficiálně zastupován při církevních slavnostech a průvodech. Již nenacházíme zmínky o vnitřní svobodě církví, naopak - „v státě demokratickém musí se zdemokratisovati také církev, respektive stav kněžský, a to dle týchž zásad, jakými se sesocialisuje život národní vůbec" (Program České strany socialistické, 1. 4. 1918, citováno podle Harna 1998: 77-78). Jakými státními prostředky mělo být zdemokratizování kněžského stavu provedeno, již uvedeno není. 
Výrazně rozpracován byl „církevní program“ $v$ programu kulturně-politickém na X. sjezdu socialistické strany v roce 1924, kde byla sledovaným oblastem věnována největší pozornost ze všech programů analyzovaných v tomto článku. Národní socialisté se odkazovali na pražské artikuly, „aby kněží světským nepanovali a zboží nedrželi“. Litovali, že církevní otázka nebyla dosud v nové republice vyřešena, takže klerikální kruhy údajně stupňují donekonečna své mocenské požadavky. Kritizovali navázání diplomatických vztahů s Vatikánem a uznání vatikánského nuncia v Praze; po špatných zkušenostech (ještě před tzv. Marmaggiho aférou v roce 1925 - viz např́ílad Večeřa 2008: 205-225) žádali zrušení československého vyslanectví ve Vatikánu. Varovali před uzavřením konkordátu. Stát měl podle prvorepublikových národních socialistů naprosto zásadně vstoupit do života církví: měl získat právo nominace církevních funkcionářŭ, zrušit trestní předpisy chránící postavení církví, stanovit nové hranice diecézí a řeholí podle hranic státních, ${ }^{5}$ snížit a posléze zrušit státní príspěvek na církevní účely, zrušit teologické fakulty, zestátnit matriky, zbylé hřbitovy převést ze správy církví na obce, zavést jen národní (nikoli náboženské) památné dny a zavést povinný občanský sňatek (Program kulturně-politický, 7.- 8. 12. 1924, citováno podle Harna 1998: 120-121).

Ve 30. letech zájem o tyto otázky v národně-socialistických programových dokumentech opadá a ve zbylých zmínkách je antiklerikální tón zmírněn. Programy znovu opakují heslo „Svobodná církev ve svobodném státě“, které nově spojují s tím, že stát nemá vykonávat vliv na církve. Konstatují, že odluka je fakticky provedena („chybí ostatně jen málo opatření, většinou rázu formálního“), nemají obavy o vliv církví na školy („naše škola je svobodná a zůstane svobodnou [...] boj ten je po našem soudu v zásadách dobojován“). Nově přicházejí s požadavkem reformy patronátního práva a s novelou daňových zákonů, aby nikdo nebyl nucen platit na kult jiné církve (Poslání československého národního socialismu, 5.-6. 4. 1931, citováno podle Harna 1998: 188-190) - nicméně jak je uvedeno výše, část z toho zahrnovala programová výbava pokrokářských stran již na přelomu století.

Sociálni demokracie ani za první republiky církevní otázku téměř neřešila. Ve svém programu z roku 1927 jen uvedla imperativ, že z církevní př́slušnosti nesmí plynout žádné výsady ve veřejném životě. Náboženství nemá být vyučováno ve školách, škola má být vedena v duchu náboženské snášenlivosti. Požadovali úplnou odluku církve od státu, což by zahrnulo i změnu ve vedení matrik, které měly převzít obce, jimž měly být dále zrušeny veškeré závazky vůči církvi (Program Československé sociálně demokratické strany dělnické, 15.-18. 4. 1927, citováno podle Prokš 1998: 188, 191).

Republikánská strana - tedy agrárníci - po roce 1918 interpretovala světovou válku mj. jako „nejstrašnější zneužití náboženství“, jež završilo předchozí zneužívání náboženství jak vysokou hierarchií, tak jednotlivci. Strana hodlala očistit náboženství od všech výstřelků, jež byly umožňovány nezdravým poměrem mezi církví a státem. Podrobnosti agrárníci neuváděli - snad jen, že prostředkem má být vhodná úprava poměru mezi státem a církví, jakož i náboženské výchovy. „Úprava taková nesmí býti ovšem pláštíkem pro jakékoli oslabení velkých hodnot mravních a kulturních vůbec, jež v sobě ryzí náboženství pro lidstvo chová“ (Návrh Programu Republikánské strany československého venkova, 29. 4. 1919, citováno

Ty totiž až do roku 1977 nerespektovaly státní hranice - například část slovenského území formálně patřila pod mad’arské diecéze apod. (srv. Balík a Hanuš 2007: 52-53). 
podle Harna a Lacina 2007: 104). Je zde patrná snaha po zaujetí středové pozice mezi pokrokářskými a katolickými požadavky.

Postupem doby je patrné přibližování se agrárníků katolickému táboru. Tak již v roce 1920 ve svém předvolebním manifestu uvádí:

Nedáme se také od nikoho poučovati o pokroku. [...] Sedlák Chelčický, selští Čeští Bratří, české dějiny pobělohorské jsou důkazem, jak nám [sedlákům] je svato a blízko náboženské hloubání. City náboženské jsou nám posvátné. [...] Proto třeba upraviti poměr mezi státem a církvemi, jež jsme neblaze zdědili po bývalé řiši. (Manifest Republikánské strany československého venkova, 18. a 25. 4. 1920, citováno podle Harna a Lacina 2007: 112)

O dva roky později stále trvá požadavek zákonné úpravy vztahů, s dovětkem, že bylo „nemoudré, chtíti úpravou poměrů státu k církvím znásilňovati jakkoli nábožensky založenou povahu celého národa“ (Program Republikánské strany zemédèlského a malorolnického lidu, 29. 6. 1922, citováno podle Harna a Lacina 2007: 133).

Tím programatický zájem agrárníků o církevní otázku pro období první republiky končí. V kontextu popsaného vývoje (opatrné a středové strategie, postupně se přibližující ke katolickým stranám) není od věci o šest týdnů překročit období první republiky a uvést citaci z programu Strany Národní jednoty, do níž agrárníci vplynuli a jíž vytvořili organizační základnu: „Škola bude národní a věŕící. Výchovu a život prolneme duchem svatováclavské tradice“ (Provolání Strany Národní jednoty k veřejnosti s nástinem nové politické orientace státu, 18. 11. 1938, citováno podle Harna a Lacina 2007: 255).

Postupně se formující komunisté, v tu chvíli ještě v podobě levice sociální demokracie, kritizovali ve svém programovém prohlášení z podzimu 1919, že chystané vyvlastnění půdy se má vyhnout zvláště kněžským a církevním velkostatkům. Dále pozorovali „zmáhající se vliv klerikálů, řádění zpátečnických živlü“ (Programové prohlášeni levice Československé sociálně demokratické strany dělnické, 5. 10. 1919, citováno podle Mervart a Musilová 2006: 8-9). Jinak je pozoruhodné, že po celou dobu první republiky komunisté církevní otázku fakticky neřešili hlavním nepř́telem jim (vedle sociální demokracie) byl kapitalismus a buržoazie. Maximem byly narážky na velký počet dělníků $\mathrm{v}$ katolické straně, respektive jejích odborech, jichž mělo být víc než ve straně sociálnědemokratické ( $Z$ projevu B. Šmerala na ustavujicím sjezdu Komunistické strany Československa, 14.-16. 5. 1921, citováno podle Št’astný 1988: 129).

Katolické strany, které na začátku éry první republiky fúzovaly v Československou stranu lidovou, prošly oproti předchozímu období výraznou změnou programatiky. Ofenzivní požadavky byly přinejmenším v prvních letech první republiky nahrazeny výrazně defétistickými, snažícími se ve změněné atmosfére zachránit alespoň něco. A tak již v návrhu programu strany v Čechách v prosinci 1918 se strana hlásí ke svobodě svědomí a svobodě vykonávání náboženství, svobodě výchovy a vyučování a práva rodičů na výchovu dětí, brání se proti svévolnému a násilnému měnění státně-církevních právních poměrů (Československá strana lidová. Návrh programu strany v Čechách, 1918, citováno podle Marek 2011: 150). Již schází požadavek proměny všech škol v křest’anském duchu, namísto něj chce strana finanční subvence pro náboženské školy. Změněná situace vedla k větě: „Jsme proti nadpoměrnému zastoupení jednotlivých vyznání v úřadech“ (,,Rámcový “ program Československé strany lidové na Moravě a ve Slezsku, 21. 12. 1919, citováno podle Marek 2011: 151-152). 
Př́slušníci lidové strany se $\mathrm{v}$ celém prvorepublikovém období výrazně vymezovali proti změně umožňující rozlučitelnost manželství a horovali pro možnost náboženských (dnes bychom řekli církevních) škol. Skončily požadavky na křest’anský charakter státu, namísto toho stačí svoboda svědomí a konání bohoslužby a samospráva církve.

Po odeznění první vlny protikatolických kroků ze strany státu se proměňují i katolické požadavky. Tak se v roce 1921 objevuje požadavek povinné výuky náboženství na všech školách, včetně škol zemědělských a hospodářských (Doplněný program Československé strany lidové na Moravě a ve Slezsku, 1921, citováno podle Marek 2011: 189). V témže roce odmítla strana nucení žáků $\mathrm{k}$ účasti na Husových oslavách a protestovala proti jakémukoli spoluužívání chrámů nově vzniklou Církví československou (Rezoluce 2. sjezdu Československé strany lidové na Moravě a ve Slezsku, 22. 5. 1921, citováno podle Marek 2011: 193). V roce 1925 deklarovala, že zabránila tomu, aby katolíci vzali zbraně na obranu svých znesvěcovaných svatyní. Tehdy také rozššríla svůj stávající minimalistický požadavek zákazu rozlučitelnosti manželství na zákaz možnosti uzavírat civilní sňatky (Provolání zemských výborů ČSL, 28. 10. 1925, citováno podle Marek 2011: 203, 206).

Ve 30. letech se pak tón programů v církevních otázkách uklidňuje, respektive umlká, nebot' se zcela vytrácí.

\section{$1945-1948$}

Pro léta 1945-1948 je typické, že se během nich otázka církví téměř vůbec neřešila. Před volbami v roce 1946 žádali sociální demokraté, aby bylo školství oproštěno od všech církevních vlivů, především aby byl stanoven zákaz vyučování náboženství ve školách (mělo se ponechat péči církví a rodin). Odmítali dělení žáků ve školách podle konfesí, stejně jako existenci církevních škol (se zdůvodněním nepřípustnosti rozdělování mládeže do různých táborů, což zcela odpovídalo dobovému požadavku národní jednoty). Výjimečný byl požadavek, aby nesměli vyučovat řeholníci a řeholnice, stejně tak aby nesměli spravovat školy. Náboženské úkony nesmějí rušit vyučování ( $O$ programu čs. sociální demokracie, Politický program $\check{C} S S D, \check{C} S L, \check{C} S N S, K S \check{C}$ 1970: 37).

Oproti tomu lidovci požadovali (se zdůvodněním, že „Boha nelze beztrestně vyloučit z dějin a poněvadž křest'anství je nejstarší a nejtvořivější silou evropské kultury“) pro katolickou církev (stejně jako pro další církve) plnou svobodu, jež měla především zahrnout svobodu na poli výchovném. Varovali před státním kulturním a školským monopolem. Navíc chtěli (což byl jeden z posledních pozůstatků kulturních požadavků ČSL předválečných dob), aby výchova ve státních školách probíhala na základě křest’anského světového názoru, „k němuž se většina národa hlási““ (Posláni Československé strany lidové, Politický program ČSSD, ČSL, ČSNS, KSČ 1970: 49).

Snad k největší proměně došlo u národních socialistů. Zatímco za první republiky představovali stranu, pro niž bylo řešení vztahu státu a církví jednou z hlavních priorit, přičemž se ve svých programových dokumentech stavěli na pozice státní supremace v otázce náboženství, v letech 1945-1948 toto téma fakticky neotevřeli. Zda to souviselo se snahou získat pravicové voliče, kteří v období třetí republiky neměli v parlamentu svou prvorepublikovou reprezentaci (zákaz agrárníků, národních demokratů), není úplně jasné. Otázka řešená 
v tomto článku stála ale každopádně zcela na okraji zájmu. Marginálně se objevila v akčním programu strany z prosince 1945 , kdy se strana přihlásila k požadavku svobody svědomí a vyznání i svobody být bez vyznání a kdy se vyslovila pro skutečnou rovnost všech církví a náboženských i bezkonfesijních společností a pro požadavek rozluky (Akční program Československé strany národně-socialistické, 8.-9. 12. 1945, citováno podle Harna 1998: 244). Naprostou změnu dikce a akcentů představoval návrh programu ČSNS pro XIV. valný sjezd v únoru a březnu 1947. Církve a náboženství byly znovu marginálním tématem, nicméně př́stup byl zcela jiný než v minulosti. Náboženství bylo oceněno jako zdroj posily a mravního upevnění a jako potřeba vnitřního života mnoha lidí. Církvím měla být ponechána „všechna volnost ve sledování jejich náboženských cílů“. Církev je oceněna jako nejmocnější a nejúčinnější nositel velkého úkolu mravní výchovy. Církve měly velký úkol spolu se školou měly provádět soustavnou mravní výchovu. Program však také konstatuje, že „dnešní církve si ovšem nejsou plně vědomy tohoto úkolu a nejsou naň připraveny. Je třeba, aby si jej uvědomily a našly své vhodné místo ve spolupráci s ostatními silami a institucemi, působícími na tomto poli““ (Návrh programu ČSNS pro XIV. valný sjezd, 27. 2. až 2. 3. 1947, citováno podle Harna 1998: 277). Fakticky šlo o návrat ke kořenům národně socialistického programu z přelomu století.

Ke svobodě svědomí a náboženského vyznání se deklaratorně hlásili i komunisté, kteří se přihlásili rovněž ke svobodě výkonu náboženských obřadů. Program ale již zahrnoval náznaky rétoriky pozdějších let:

Domníváme se, že není nebezpečný ten, kdo v Boha upř́ímně věrí, ale ten, kdo Boha zneužívá a kdo pod pláštíkem náboženství sleduje dnes reakční, protidemokratické, protisociální a v podstatě i protikřest’anské snahy. [...] Od vlasteneckých a demokratických kruhů katolické církve očekáváme, že budou věrně stát při republice proti všem intrikám, jež vycházejí z Vatikánu, který protežuje poražené Němce, který napomáhá ještě dnes fašismu ve Španělsku a který je zaujat proti našemu spojenci, Sovětskému svazu. (Komunistická strana Československa, Politický program ČSSD, ČSL, ČSNS, KSČ 1970: 85)

V rozporu se svou jen o několik let pozdější praxí (zrušení adventistické církve v roce 1952 apod.) deklarovala KSČ, že chce poskytnout státní uznání všem církvím; stejné legality a rovnoprávnosti se ale mělo dostat i hnutí bezvěrců.

Na dokreslení jedné zajímavé proměny si všimněme exilové agrárnické deklarace z podzimu 1948. Agrárníci, kdysi vzešlí z pokrokářských kruhů, se po svém zákazu v roce 1945 a přesídlení části svých reprezentantů do exilu jednoznačně postavili na katolické pozice:

Zahájili jsme svou činnost mší svatou a slíbili jsme, že po návratu do vlasti postavíme na památném Blaníku k poctě národního patrona sv. Václava velechrám. Jsme přesvědčeni, že nad statky materielní vysoko stojí hodnoty ducha, tj. mravnost a náboženství. Hlásíme se k praporu křest’anské kultury, k zásadám Nového zákona, jak jej vyslovil Kristus Pán. [...] Zavazujeme se pracovat v duchu křest’anské solidarity a lásky. Vy, kteří jste stáli dne 12. prosince 1933 u otevřené rakve Antonína Švehly, pod prostým křížem, nevzpomínáte si, že tento velký apoštol lásky, tento rozsévač zrn pochopení, vyřknul řád, který je blízký zákonu Božímu, protože je zákonem Boží přírody, zákonem lidského nitra a srdce? (Svatováclavská deklarace, 28. 8. 1948, citováno podle Harna a Lacina 2007: 265) 


\section{8-1989}

Etapa české politiky mezi lety 1948 a 1989 byla v lecčems radikálně nová (nicméně v řadě ohledů navázala na předchozí trríletí). Týkalo se to i změn v postavení církví (zvláště katolické). Nicméně při znalosti výše zachycených programových požadavků je zřejmé, že KSČ nepřišla s něčím do té doby nepředstavitelným - do značné míry ,pouze“ naplnila programové požadavky jistých politických proudů, jež byly staré přes půl století. Týkalo se to jak odebrání vedení matrik církvím, zrušení civilněprávních účinků církevních sňatků, zrušení církevních škol, zrušení československého vyslanectví ve Vatikánu, předání výkonu správy církevních záležitostí ministerstvu vnitra apod. Komunisté leckdy až doslovně přebrali i rétoriku někdejších bojovníků proti vlivu církví ve společnosti.

V řadě ohledů ovšem komunistický režim zasáhl do života církví způsobem do té doby nepředstavitelným. V letech 1950-1951 zůstal na svobodě v celém Československu jediný katolický biskup, zbývajících 21 biskupů bylo bud' přímo uvězněno, nebo internováno bez soudu. Tři kněží byli popraveni, desítky jich zemřely ve věznicích, stovky byly vězněny. Mužské řehole byly de facto (nikoli de iure) zakázány, řeholníci internováni v internačních táborech. V menší míre se represe dotkla ženských řeholí. Téměř pět set řeholnic a řeholníků bylo prŕmo vězněno. Výrazné represe se dotkly i křest’anů-laiků.

Snad nejvýrazněji se do života církví zapsal institut tzv. státního souhlasu, kdy duchovní, chtěl-li vykonávat svou službu, musel mít souhlas patřičného církevního tajemníka (okresního či krajského národního výboru). Trestní zákoník navíc stanovil trestný čin porušení této povinnosti - zpověd’ či sloužení bohoslužby v soukromém bytě se tak stalo trestným činem. Omezení se nevztahovala pouze na římskokatolickou církev, ale v různé míře i na ostatní denominace. Některé z nich byly přímo zrušeny - řeckokatolická církev, adventistická církev (o prŕístupu státu ke katolické církvi blíže viz Balík a Hanuš 2007).

\section{Po roce 1989}

Listopadové události roku 1989 přinesly občanům tehdejší československé federace plný rejstřík občanských svobod, které byly nejenom ústavně zakotvené, ale i fakticky respektované. Mezi těmito svobodami byla samozřejmě i svoboda vyznání. Po čtyřech dekádách nadvlády fakticky ateistického a společnost destruujícího režimu se objevil prostor pro obnovu vztahu státu a církví. Postupně se však ukázalo, že tento úkol nebude nijak snadný. Ačkoliv některé aktivity církví veřejnost hodnotila a hodnotí pozitivně (jako například zřizování církevních škol, správa zdravotně-sociálních zařizení či aktivní působení v armádě a vězeňské službě atd.), jiné jsou vnímány velmi negativně. Jde zejména o restituční požadavky církví, které je v očích většinové veřejnosti spíše poškozují. Tato situace má kořeny na začátku 90. let 20. století a je do značné míry aktuální i dnes: ačkoliv je církvím často přiznávána nezastupitelná role v mnoha oblastech (společenského a duchovního) života, ekonomické vztahy církve a státu jsou stále otevřené a jsou zdrojem neshod na mnoha úrovních (nejen) politiky (srv. Balík a Ondráčková 2010: 90).

I přesto, že vztah církví a veřejnosti není jednoznačný, problematika církví se v polistopadové éře nikdy nestala nejdůležitějším tématem, takovým, které by přitahovalo pozornost politické reprezentace jako celku, poprrípadě široké obce voličů, a bylo tak hybnou 
silou politického konfliktu v Československu, popřípadě v České republice. ${ }^{6}$ Pokud již došlo k tomu, že se veřejně diskutovala témata s církví spojená, šlo (a stále jde) o prŕípady, které souvisely především s již zmíněnými ekonomickými otázkami (restituce církevního majetku, dohady okolo vlastnictví katedrály sv. Víta na pražském Hradě), s otázkami souvisejícími se zahraniční politikou (tzv. smlouva se Svatým stolcem) či s nejrůznějšími skandály kněží a dalších církevních představitelů. Po roce 2001 a útocích na World Trade Center se pak objevují zmínky o nutnosti bojovat s náboženským extremismem (např́klad v programu ODS).

O tom, že vztahy státu a církve nejsou hlavním tématem, svědčí i jeho reflexe v programových dokumentech politických, která je spíše sporadická. Vlastní kapitoly v programech mají církve skutečně málokdy, častěji je problematika církví součástí kulturní politiky obecně. I přesto ale dokážeme mezi stranami (a např́ič časem) najít poměrně významné rozdíly.

Československá strana lidová (ČSL, později Křest’anská a demokratická unie Československá strana lidová - KDU-ČSL) se bezprostředně po listopadových událostech v roce 1989 explicitně přihlásila ke křest’anským kořenům. Ve svém programu (jakožto hlavní součást předvolební koalice Křest'anská a demokratická unie) pro volby 1990 nejprve odsoudila destruktivní působení kolektivistického ateistického totalitního systému a vytyčila si za cíl vytvoření civilizace lidí dobré vůle a civilizace lásky. Takový stav má nastat obnovou a rozvíjením křest’anských hodnot, které mají tvořit pilíř nové společnosti, a znovuobnovením lásky k vlasti, do níž se promítají jak národní tradice a kultura, tak křest’anské základy, na nichž byl český stát po staletí budován. ${ }^{7}$ ČSL proto vyslovila podporu těm institucím, které budou tyto hodnoty ve společnosti upevňovat - šlo zejména o podporu takových institucí, jako jsou rodina, škola, ale i křest’anské kluby mládeže (popř́padě podobné organizace), a samozrrejmě církví. Náboženství ČSL chápala jako „důležitý předpoklad pro vytváření mravních hodnot a kultury ducha“, a proto bylo nutné „církvím a církevním společnostem v ekumenickém smyslu zajistit důstojné postavení, autonomii struktur a vnitřního života“ (Volební program ČSL 1990). Kromě obnovy duchovních rozměrů života pak ČSL usilovala o vstup církevních organizací do oblasti zdravotnictví a sociálních služeb. Církevní rády a charitativní organizace měly zlepšovat stav poskytovaných služeb a naplňovat tak poslání služby bližnímu.

Tento základní postoj se pak s větší či menší intenzitou objevuje (a je rozvíjen) i v budoucích programech KDU-ČSL. Žrejmě největší důraz na své hodnotové zázemí a na odkazy k římskokatolické církvi KDU-ČSL vložila do programu pro volby v roce 1992. V tomto programu se objevuje pojem „,křest’anského solidarismu“, který v sobě zahrnuje požadavek „na spolupráci všech společenských vrstev v zájmu prosperity a udržení sociálního smíru“

6 Jako výjimku můžeme chápat snahu některých stran - zejména pak ČSSD - o využití problematiky restitucí církevního majetku v kampani proti vládě Petra Nečase, respektive v kampani v krajských volbách 2012 (viz např́iklad Eibl, Gregor a Macková 2013).

7 V této souvislosti v roce 1992 strana zmiňuje historické milníky, které napomohly formování pozdějšího českého státu: jsou jimi zejména události spojené s příchodem Cyrila a Metoděje a éra panování sv. Václava a Karla IV. 
(Průvodce politikou KDU-ČSL 1992). Současně se v tomto programu objevil zajímavý prvek, který měl zřejmě KDU-ČSL legitimizovat v očích širší veřejnosti jako relevantní stranu s kvalitním politickým obsahem. Křest’anští demokraté totiž opakovaně poukazovali na to, že vstoupili do Evropské křest’anskodemokratické a lidové unie (i do unie světové) ${ }^{8}$ a že za dlouhou historii své existence byli již českému státu prostřednictvím svých představitelů prospěšní. KDU-ČSL se tak přihlásila k podílu na obnově křest’anské Evropy, jejímž duchovním centrem se Česká republika měla stát:

Hlavní př́nos do budoucí Evropy přrištího tisíciletí nevidíme pouze v oblasti hmotné, ale především v duchovní obnově, v návratu $\mathrm{k}$ nejvyšším hodnotám křest’anské civilizace, usilující o mírovou spolupráci s ostatními oblastmi světa. (Průvodce politikou KDU-ČSL 1992) ${ }^{9}$

V dalších volebních programech (od roku 1996) je akcent na „blízkost“ římskokatolické církve snižován. Jádrem ideologie strany ale zůstávají hodnoty a (etické) normy, které do základů evropské civilizace vložilo křest'anství - tedy úcta k životu, svobodě, odpovědnosti, spravedlnosti a solidaritě. Výraz „křestanský solidarismus“ používaný v roce 1992 je stř́dán neutrálnějším spojením „sociálně tržního hospodářstvi““ (tento pojem se pak objevuje ve všech dalších programech KDU_ČSL s výjimkou programu Koalice z roku 2002). Je zde tedy patrná snaha částečně oslabit explicitní křest'ansky laděnou rétoriku. Stejně tak zde zůstávají odkazy k prospěšné činnosti církví v oblasti vzdělávání, práce s mládeží, sociální péče či zdravotnictví. A uspořádání mezi církvemi a státem by mělo být takové, že církve budou mít ve společensky prospěšných oblastech dostatečný prostor pro spolupráci se státem.

Od roku 1996 KDU-ČSL ve svých volebních programech vznáší požadavky na navrácení církevního majetku, v roce 1998 pak přidávají křest’anští demokraté požadavek, aby se stát spolupodílel na financování oprav a údržby architektonického dědictví a památek, které církve spravují.

Do voleb v roce 2002 KDU-ČSL vstupovala v koalici s Unií svobody a důraz na církevní záležitosti je zde opět o něco slabší než v předchozích programových dokumentech, byt' odkaz $\mathrm{k}$ tradici a hodnotám je stále prítomný. $\mathrm{V}$ programu se ale neobjevuje ani požadavek na navrácení církevního majetku. Pouze mají být zachovány podmínky, aby mohly církve plnit nezávisle svou tradiční veřejně prospěšnou roli v oblasti sociálních a zdravotních služeb. Požadavek na navrácení církevního majetku se do programu KDU-ČSL ale vrací už v roce 2006, společně s deklarací podpory zvýšení kapacity církevních škol a jejich dostatečného finančního zajištění.

8 V této souvislosti program obsahoval celou řadu odkazů na fakt, že v zemích západní Evropy jsou často křest'anskodemokratické strany součástí vládních koalic, a jsou tedy zodpovědné za společnost blahobytu a rozvětvenou podobu sociálního státu.

9 Vzorem KDU-ČSL přitom měla být holandská Křest’anskodemokratická aliance (CDA), jejímž cílem (se kterým se KDU-ČSL ztotožnila) byla obnova „křest’anské Evropy, všech složek společenského života a zvláště její kultury, založené na duchovním životě podle Kristova učení lásky k Bohu a bližnímu, zahrnujícím respektování všech lidských práv jednotlivců i menšin a vedoucím k mírové spolupráci a spolužití všech národů a států“ (KDU-ČSL 1992). 
Občanské fórum (OF) v roce 1990 pouze (podobně jako ČSL) konstatovalo neutěšený stav náboženského života, který komunismus - navzdory tisícileté kulturní tradici - potlačil. Zároveň se v programu objevil príslib, že kulturní politiku chtělo OF opírat „o zásadu svobody umělecké tvorby, kulturní a náboženské činnosti i svobody informací" (Volební program OF „Přijmout odpovědnost za vlastní budoucnost“ 1990).

Před volbami v roce 1992 došlo k rozpadu OF a ke vzniku nových politických stran, mezi nimiž byla i Občanská demokratická strana (ODS). Ta se v programu v roce 1992 přihlásila $\mathrm{k}$ tomu, že vychází z „tradičních hodnot evropské civilizace. Mezi nimi na prvním místě stojí tradice a hodnoty křest’anské, úcta k pravdě a láska k bližnímu“ (Volební program ODS „Svoboda a prosperita“ 1992). Téměř okamžitě se ale strana vymezila vưči př́lišné blízkosti k církvím: „,[ODS] ovšem není stranou, která se sama prohlašuje za křest’anskou, a už vůbec ne stranou konfesijní“ (tamtéž). Křest’anství ODS chápala jako duchovní odkaz minulosti a kladla důraz na praktické aspekty tohoto odkazu, které se promítají do oblasti demokratické politiky: svobodu, rovnost a solidaritu. ODS ocenila nové svobodné prostředí, ve kterém je možné garantovat plnohodnotnou činnost církví, a v této souvislosti vyjádřila podporu vzniku a pưsobení nestátních (tedy i církevních) subjektů v oblasti sociální péče, zdravotnictví a školství.

V dalších volebních programech už se ODS ke křest’anským hodnotám nehlásí (přes své sloučení s Křest’anskodemokratickou stranou v letech 1995-1996), zůstává zde však pozitivní vnímání církevních organizací v oblasti vzdělávání, péče o seniory či postižené apod. Problematika vztahu církví a státu se $\mathrm{v}$ dalších programových dokumentech stává součástí (většinou) stručných kapitol věnovaných kulturní politice (v roce 1998 ani v roce 2002 program problematiku církví nezmiňuje vůbec) a je redukována na konstatování svobody a tolerance, popř́padě na problematiku církevních restitucí. V roce 1996 ODS deklaruje úmysl „legislativně, věcně i majetkově dořešit vztahy mezi státem a církvemi tak, aby církve nadále fungovaly nezávisle na státu a aby mohly pokračovat ve všech svých veřejně prospěšných činnostech“ (Volebni program ODS 1996). Program z roku 2006 pak konstatuje, že k takovému narovnání stále nedošlo kvůli neexistenci dostatečné podpory jak mezi politickou reprezentací, tak mezi církvemi samotnými. Současně tento program posouvá víru a př́slušnost $\mathrm{k}$ jednotlivým náboženstvím do striktně osobní soukromé sféry (víra je tedy privatizována), do které se stát nesmí vměšovat, a dává neurčitý slib (který zopakuje i v roce 2010), že ODS bude hledat takové řešení stávajícího vztahu církve a státu, které zachová možnost svobodného vyznání pro každého občana a které neohrozí postavení církví v České republice.

Program do voleb v roce 2010 se k tématu restitucí vrací a konstatuje, že zablokovaný církevní majetek znemožňuje rozvoj obcí a měst. ODS se proto chtěla snažit o dokončení transformace vztahu státu a církví, respektive o postupné ekonomické oddělování církví od státu a o dořešení majetkových vztahů.

Česká strana sociálně demokratická (ČSSD) se k problematice vztahu církve a státu poměrně dlouho ve svých programových dokumentech nevyjadřovala, a pokud se objevila nějaká zmínka, byla maximálně stručná. $V$ roce 1990 tak v jejím programu bylo pouze stručné konstatování, že ČSSD „bude podporovat zaručené právo na náboženské vyznání, náboženskou snášenlivost a odluku církve od státu. Náboženství je osobní věcí každého občana“ (Program Československé sociální demokracie schválený XXIV. sjezdem ve dnech 24.-25. 
března 1990). ČSSD tak jako první ze stran „zprivatizovala“ duchovní život bezprostředně po pádu komunistického systému, a navázala tak na svou předkomunistickou programatiku.

Problematika církví se pak v programu sociálních demokratů objevuje až v roce 1996, kdy ČSSD vyjádřila církvím respekt a přiznala křest’anství a náboženským společenstvím význam pro vznik moderní evropské společnosti. Strana vyzdvihla zejména kritický vztah církví k morálnímu stavu společnosti, konkrétně $\mathrm{k}$ tržnímu hospodářství bez př́vlastků (v této souvislosti šlo i o vymezení se vůči politice stran jako byly ODA či ODS; výše jsme zmínili, že v roce 1996 KDU-ČSL přichází s pojmem „sociálně-tržního hospodářství"). Po této opět stručné zmínce problematika církví z programu ČSSD mizí a objevuje se znovu až v roce 2006. Kromě uznání důležitosti a př́nosu církví ke kvalitě společenského života se v programu objevila deklarace, že pokud církve a náboženské společnosti plní obecně prospěšné aktivity v oblasti charitativní, zdravotní, sociální a vzdělávací, bude ČSSD napomáhat řešení jejich hospodářského zajištění. ČSSD se dále přihlásila $\mathrm{k}$ př́pravě úpravy právních vztahů s církvemi (mj. problematika církevních restitucí) a k ratifikaci smlouvy mezi Českou republikou a Vatikánem. V roce 2010 se už velký program ČSSD k církevním restitucím nehlásí, na druhou stranu je vůbec nezmiňuje (zmínky však nacházíme v tzv. malém programu, kde ČSSD restituce označuje za jeden z megalomanských projektů Topolánkovy vlády, který je třeba omezit, a v kultuře věnované kapitole Oranžové knihy [ČSSD 2010], kde sociální demokraté navrhují „,dokončit majetkové narovnání mezi státem na straně jedné a církvemi a náboženskými společnostmi na straně druhé, ke kterému je však třeba dojít všeobecným konsensem a vzájemnou vyvážeností požadavků obou stran"). Církve a náboženské společnosti jsou diskutovány společně $\mathrm{s}$ dalšími neziskovými organizacemi, zejména jako důležité komponenty občanské společnosti. A to zejména pro jejich prospěšné aktivity v charitativní, zdravotní, sociální a vzdělávací oblasti.

Komunistická strana Československa, respektive Komunistická strana Čech a Moravy (KSČM), má k církevním záležitostem vysloveně rezervovaný vztah. Volební programy z let 1990 a 1992 vůbec téma církví neotevírají, v roce 1996 se pak objevuje požadavek na důslednou odluku církve od státu a školy. KSČM dále vznesla požadavek, aby se potřeby věřících hradily pouze z prostředků církví a dobrovolných příspěvků věřících (jasně zde slyšíme ozvuk pokrokářských a národně socialistických programů z první čtvrtiny 20. století). V roce 1998 KSČM reagovala na debatu o církevních restitucích, kterou do svých programů v roce 1996 zařadila většina stran, a požadovala zastavení restitucí na objekty památkové péče, respektive ukončení restitucí a provedení „revize velkých restitučních rozhodnutí ve prospěch církve a osob s problematickými nároky“ (Volební program KSČM 1996-2000 „,Socialismus - šance pro budoucnost "). V letech 2002, 2006 a 2010 je v programu KSČM řešeno financování církevních škol - podobně jako $v$ prípadě škol soukromých mají být tyto školy (z velké části) financovány jejich zřizovatelem (s výjimkami danými veřejným zájmem) pod dohledem státu tak, aby byla výuka založena na světonázorové neutralitě a soudobých vědeckých poznatcích (šlo o odmítání snah nadřazovat vědeckým poznatkům jakýkoli náboženský světonázor).

Program KSČM z roku 2006 obsahuje zmínek o církvích více. Vesměs jde o proklamace, které mají zajistit respekt a rovnoprávnost všech náboženství (i ateistů), která přispívají ke kultivaci člověka a jsou v souladu s platnými zákony. Současně ale komunisté formulovali distanc od církevních záležitostí: KSČM se opět vyslovila pro odluku církví od státu 
a zdůraznila podřízenost církví platným zákonům (které nejsou a nemohou být dotčeny ani mezinárodními smluvními dokumenty, jako je např́klad smlouva s Vatikánem). Dále KSČM poukázala na skutečnost, že církve musí být rovnoprávné s ostatními občanskými sdruženími - bez dalších výsad v jakékoliv oblasti jejich činnosti (tedy včetně financování). V této souvislosti navrhli komunisté daňové asignace - občané sami měli mít možnost rozhodnout, jaké organizaci věnují část svých daní. Program se vyjadřoval i k problematice navracení majetku - KSČM byla v tomto tématu konzistentní: usilovala o ponechání historických kulturních památek (vč. katedrály sv. Víta) ve vlastnictví státu (jejich údržba měla být hrazena z veřejných prostředků) a o ukončení restitucí (žádné další vydávání majetku církvím). V podobném duchu se pak nesla i argumentace programu pro volby 2010.

Následující část textu se věnuje stranám, které byly v dolní komoře přítomny jen v některých funkčních obdobích. Občanská demokratická aliance (ODA) se ve svém programu z roku 1992 přihlásila k tradičním kulturním hodnotám, které z křest’anství vychází, a v další argumentaci formulovala požadavek na odluku církve od státu. Každá církev a náboženská společnost měla mít právo konstituovat se jako právnická osoba. ODA dále vyslovila úctu k činnosti církví a náboženských organizací, jejichž činnost má na společnost pozitivní dopad, a ocenila je za jejich podíl na „vytváření mravního vědomí společnosti i jejich konkrétní prínos ve sféře jak bezprostředně duchovní a náboženské, tak i výchovné, charitativní, sociální a kulturní“ (Volební program ODA 1992). V této souvislosti pak podpořila vícezdrojové financování zdravotnictví, přičemž jedním ze zdrojů měly být právě charitativní organizace a církve. V programu z roku 1996 se pak objevil požadavek na další zlepšování podmínek, ve kterých tyto organizace (a církve obecně) fungují.

Liberálně sociální unie, tedy předvolební koalice Strany zelených, Československé strany socialistické, Zemědělské strany a Hnutí zemědělců a nezávislých osobností z roku 1992, se ve svém programu přihlásila k obecným humanitním ideálům a lásce k vlasti, nikoliv však přímo ke křest’anským hodnotám. Program odmítl restituci majetku ,pobělohorské šlechtě, neúměrného majetku církvím, zrádcům a kolaborantům z dob nacistické okupace“ (Realizační program LSU „Československo sobe““ 1992).

Sdružení pro republiku - Republikánská strana Československa v roce 1992 ústy svého předsedy M. Sládka (1992) odmítla stav, kdy podle nich dochází ke splývání státu a církve (respektive zpolitizování církve), zejména v tom smyslu, že duchovní dávají doporučení, koho by měli věřící ve volbách volit. Dominantním heslem Sládkových úvah o vztahu církve a státu byla tolerance - a to jak mezi různými církvemi, tak mezi věřícími a ateisty. A tedy i „depolitizace“ duchovních - řešením má být odluka státu od církve a nastolení stavu, kdy církve (bez rozdílu) budou moci bez problémů vykonávat své poslání (i formou aktivit v oblasti vzdělávání, dobročinnosti, sociální a zdravotní péče a péče o kulturní památky) a kdy budou za určitých podmínek moci čerpat státní finanční příspěvky (i formou úlev) na tuto činnost. V otázce navracení církevního majetku Sládek uváděl, že by se církvím vrátila jen taková část majetku, která jim umožní vykonávat výše zmíněné aktivity. Veškerý majetek tedy navrácen být neměl. V roce 1996 se v programovém dokumentu republikánů objevuje bod, který hovoří o vytváření podmínek pro rozvoj církevního (a soukromého) školství, ovšem tyto školy by měly být financovány prostředky rodičů dětí školy navštěvujících. Další zmínky o působení církví v programu nenacházíme. 
Podobně jako KDU-ČSL, ODA a ODS i Unie svobody (US) konstatuje v roce 1998 nezastupitelnou úlohu církví při obnově etických základů života naší společnosti a propojování naší kultury s kořeny evropské civilizace. US se vyslovila pro odluku církví od státu, zároveň však konstatovala, že stát by se měl zasadit o to, aby byly vytvořeny podmínky pro bezproblémové fungování církví a náboženských organizací. To v pojetí US zahrnovalo mj. i dokončit restituce církevního majetku (nebot' „nedořešený vztah mezi církvemi a státem představuje překážku naší plné a stabilní integrace do euroatlantické civilizace“; Volební program US 1998 „Nová volba“) a zavést do daňového systému asignace, pomocí nichž by měly být církve financovány. A podobně jako další strany chtěla US zlepšit i podmínky pro rozvoj soukromých, nestátních i církevních institucí sociální péče. V roce 2002 kandidovala US ve volbách společně s KDU-ČSL, programové body vztahující se $\mathrm{k}$ církvím ale program prakticky neobsahoval.

Strana zelených v roce 2006 ve svém programu kladla důraz na multikulturalismus a odmítala stereotypy vůči islámu. Současně zelení v programu deklarovali snahu o iniciaci legislativního procesu v otázce odstraňování faktických nerovností mezi jednotlivými náboženskými subjekty. Podobně se vyslovili pro to, aby veřejnoprávní média zajišt’ovala vysílání o menšinách a pro menšiny (nejenom etnické a náboženské). Církve a další organizace (jako škola, rodina, státní orgány, místní a krajská samospráva, média veřejné služby a další občanská sdružení) se mají podílet na odstraňování xenofobních a rasistických předsudků.

TOP 09 se v roce 2010 pozitivně vyslovila $\mathrm{k}$ historické a nezastupitelné roli církví a náboženských společností. Jako cíl si TOP 09 dále vytyčila uzavř́t otázku vyrovnání mezi církvemi a státem, aby církve mohly své poslání plnit nezávisle na státu.

Věci veřejné $\mathrm{v}$ roce 2010 usilovaly o tolerantní a rovný př́stup $\mathrm{k}$ vírám a vyznáním a podobně jako US v roce 1998 a jako KSČM v roce 2002 do svého programu zařadily zavedení daňových asignací. Daňový poplatník měl mít možnost odvádět $2 \% \mathrm{z}$ daňové sazby organizaci podle svého uvážení. Dále VV vyjádřily úmysl zcela se vypořádat (především) s římskokatolickou církví. Sakrální stavby, s výjimkou katedrály sv. Víta na Pražském hradě, měly být navráceny, ostatní majetek (polnosti a lesy) měly být převedeny na obce a stát. Současně chtěly VV stanovit roční státní příspěvek církvím na údržbu kostelů.

\section{Závèr}

Cílem tohoto textu bylo představit a popsat dynamiku vývoje změn, ke kterým došlo v postojích politických stran působících na území dnešní České republiky ke vztahu církve-stát, a to od doby zrodu moderních politických stran až do roku 2010.

Jako pozoruhodné se jeví, že velká část požadavků, jak byly formulovány většinou českých politických táborů před rokem 1948 (s výjimkou tábora katolického, který neuspěl), došla dříve či později naplnění. Již před rokem 1918 se žádalo důsledné oddělení církví od škol, k čemuž došlo jak částečně po vzniku Československa, tak definitivně po roce 1948. KSČ po roce $1948 \mathrm{v}$ církevně-právní oblasti do značné míry pouze naplnila národně socialistické programy z let 1918 a 1924 (odebrání matrik církvím, zrušení civilněprávních účinků církevních sňatků, zrušení československého vyslanectví ve Vatikánu, odstranění teologických fakult ze svazků univerzit, právo nominovat církevní funkcionáře). Zrušením církevních 
škol byl naplněn požadavek Národní strany práce z roku 1925, jejž v roce 1945 „oprášila“ sociální demokracie; zrušením mužských klášterů byl splněn programový bod státoprávní strany z roku 1899. Nápad zrušit veškeré církevní svátky a zavést jen národní památné dny (národní socialisté 1924) se nenaplnil zcela - Vánoce a Velikonoce zůstaly zachovány. Zvláštním př́padem zůstal mnohokrát a různými proudy opakovaný požadavek vykázání výuky náboženství ze škol. To oproti jiným zemím východního bloku v Československu ve školách (jako nepovinný předmět) zůstalo, nicméně jen jako nástroj kontroly a disciplinace, kdy stát zakazoval jeho výuku kdekoli jinde. Na leckteré požadavky nestačila ani komunistická vláda - jako třeba na návrhy pokrokářských stran před rokem 1918, aby stát církvi nařídil při bohoslužbách používat národní jazyk. Jako o tři čtvrti století uspíšená se jeví formulace mladočechů z roku 1874, že zastánci ultramontanismu (pro rétoriku poúnorové doby lze synonymně zaměnit za termín ,vatikánští agenti“) jeví „,̌̌ivější interes pro zájmy zpátečnické a cizé, než pro zájmy a potřeby samého národa“.

Po roce 1989 se problematika vztahu státu a církve dostala (po krátkém, mimořádném intermezzu roku 1990) zcela na okraj zájmu. Všechny relevantní stranické subjekty jsou po roce 1989 v církevně-právních otázkách programaticky v zásadě koherentní - nebyl zaznamenán žádný programový ,veletoč“, jako tomu bylo u národních socialistů před rokem 1948. Tam šlo dokonce o veletoč dvojitý - nejprve se ze strany, pro niž stála otázka církví spíše na okraji zájmů, po roce 1918 stal největší proticírkevní bojovník, aby pak v roce 1947 došlo k opačnému posunu směrem k obhajobě církví. A tak zatímco pro KDU-ČSL se stalo křest’anství (reprezentované především křest’anskými církvemi) zdrojem politiky a základním kamenem hodnot, které strana prosazuje, pro ostatní je to především technická a osobní záležitost. Politické strany se fakticky shodly na kooperačním světském modelu spojeném s konceptem privatizace náboženství. Je patrné, že církevní organizace se stávají v pojetí stran do značné míry „servisními“ organizacemi a berou na sebe některé aktivity, které jsou jinak v režii státu (sociální služby). V programatice zaujímají církve místo (pokud se tam vůbec objeví) pouze v souvislosti s řešením církevních restitucí, popř́ípadě ve sporu o vlastnictví svatovítské katedrály.

\section{Literatura}

BALÍK, Stanislav a Dominika J. ONDRÁČKOVÁ. Církevní politika. In: BALÍK, Stanislav, Ondřej CÍSAŘ a Petr FIALA, eds. Veřejné politiky v České republice v letech 1989-2009. Brno: Centrum pro studium demokracie a kultury, 2010, s. 73-113. ISBN 978-80-7325-236-6.

BALÍK, Stanislav a Jiří HANUŠ. Katolická církev v Československu 1945-1989. Brno: Centrum pro studium demokracie a kultury, 2007. ISBN 978-80-7325-130-7.

BALÍK, Stanislav, Vít HLOUŠEK, Jan HOLZER a Jakub ŠEDO. Politický systém českých zemí 1848. Brno: Mezinárodní politologický ústav MU, 2003. ISBN 978-80-210-4250-6.

BERGER, Peter L. Vzdálená sláva: hledání viry ve věku lehkověrnosti. Brno: Barrister \& Principal, 1997. ISBN 80-85947-18-8.

BLUMLER, Jay G. a Dennis KAVANAGH. The third age of political communication: Influences and features. Political Communication. 1999, roč. 16, č. 3, s. 209-230. ISSN 1058-4609. 
DALTON, Russel J. Citizen Politics: Public Opinion and Political Parties in Advanced Industrial Democracies. 5th ed. Washington, DC: CQ Press, 2008. ISBN 0872895378.

EIBL, Otto. Politický prostor a témata v České republice v letech 2006-2008. Brno: Centrum pro studium demokracie a kultury, 2011. ISBN 978-80-7325-262-5.

EIBL, Otto, Miloš GREGOR a Alena MACKOVÁ. Témata předvolebních kampaní v programech stran, jejich outdoorových kampaních a médiích. In: BALÍK, Stanislav, Vlastimil HAVLÍK a Michal PINK, eds. Krajské volby 2013. Brno: Centrum pro studium demokracie a kultury (v tisku).

FASORA, Lukáš, Jiří HANUŠ a Jiří MALÍŘn, eds. Sekularizace českých zemí v letech 1848-1914. Brno: Centrum pro studium demokracie a kultury, 2007. ISBN 978-80-7325-117-8.

FASORA, Lukáš, Jiří HANUŠ a Jiří MALÍŘ, eds. Sekularizace venkovského prostoru v 19. století. Brno: Centrum pro studium demokracie a kultury, 2009. ISBN 978-80-86488-55-4.

GAUCHET, Marcel. Odkouzleni světa: dějiny náboženství jako věci veřejné. Brno: Centrum pro studium demokracie a kultury, 2004. ISBN 80-7325-037-3.

HALÍK, Tomáš. Vzýván i nevzýván. Praha: Nakladatelství Lidové noviny, 2004. ISBN 80-7106-692-3.

HALLIN, Daniel C. a Paolo MANCINI. Americanization, globalization, secularization: Understanding the convergence of media systems and political communication. In: ESSER, Frank a Barbara PFETSCH, eds. Comparing political communication: theories, cases, and challenges. Cambridge: Cambridge University Press, 2004, s. 25-44. ISBN 0521535409.

HLOUŠEK, Vít a Lubomír KOPEČEK. Konfliktni demokracie: moderní masová politika ve střední Evropě. Brno: Mezinárodní politologický ústav MU, 2004. ISBN 80-210-3449-1.

KOPEČEK, Lubomír. Politické strany a stranické systémy ve srovnávací a teoretické perspektivě. In: STRMISKA, Maxmilián, Vít HLOUŠEK, Lubomír KOPEČEK a Roman CHYTILEK, eds. Politické strany moderni Evropy. Praha: Portál, 2005, s. 9-54. ISBN 80-7367-038-0.

KRUKOWSKI, Józef. Aktuální problémy polského konfesního práva. Revue pro církevní právo. 1998, roč. 4, č. 11, s. 149-174. ISSN 1211-1635.

MALÍR̆, Jiří a Pavel MAREK, eds. Politické strany: vývoj politických stran a hnutí v českých zemích a Československu 1861-2004. 1. díl. Brno: Doplněk, 2005. ISBN 80-7239-178-X.

MAREK, Pavel. Český katolicismus 1890-1914. Olomouc: Gloria, 2003. ISBN 80-86200-76-0.

MAREŠ, Miroslav a Petr FIALA. Programatika politických stran. Politologický časopis, 1998, roč. 5, č. 1, s. 5-20. ISSN 1211-3247.

MAZZOLENI, Gianpietro a Winfried SCHULZ. 'Mediatization' of politics: A challenge for democracy? Political Communication. 1999, roč. 16, č. 3, s. 247-261. ISSN 1058-4609.

McLEOD, Hugh. Sekularizace v západni Evropě (1848-1914). Brno: Centrum pro studium demokracie a kultury, 2008. ISBN 978-80-7325-161-1.

NEŠPOR, Zdeněk a Dušan LUŽNÝ. Sociologie náboženství. Praha: Portál, 2007. ISBN 978-80-7367251-5.

ROKKAN, Stein a Seymour M. LIPSET. Party Systems and Voter Alignments: Cross-National Perspectives. New York: Free Press, 1967. ISBN 0029191505.

SLÁDEK, Miroslav. ... a tak to vidím já. Praha: Nadas-AFGH, 1992. ISBN 8070301724.

SWANSON, David L. Transnational trends in political communication: conventional views and new realities. In: ESSER, Frank a Barbara PFETSCH, eds. Comparing political Communication: Theories, Cases, and Challenges. Cambridge: Cambridge University Press, 2004, s. 45-63. ISBN 0521535409.

THOMASSEN, Jacques. Introduction. In: THOMASSEN, Jacques, ed. The European Voter. Oxford: Oxford University Press, 2005, s. 1-21. ISBN 0199273219.

TRETERA, Jiří R. Stát a cirkve v České republice. Kostelní Vydří: Karmelitánské nakladatelství, 2002. ISBN 80-7192-455-5. 
VEČĔ̌A, Pavel. Marmaggiho aféra: úloha katolicismu optikou dobových tištěných médií levice. In: MAREK, Pavel, ed. Teorie a praxe politického katolicismu 1870-2007. Brno: Centrum pro studium demokracie a kultury, 2008, s. 205-225. ISBN 978-80-7325-152-9.

VIDO, Roman. Konec velkého vyprávění? Sekularizace v sociologické perspektivě. Brno: Centrum pro studium demokracie a kultury, 2011. ISBN 978-80-7325-266-3.

\section{Prameny}

CIBULKA, Pavel, ed. Politické programy českých národních stran 1860-1890. Praha: Historický ústav AV ČR, 2000. ISBN 8072860208.

ČSL 1990. Volební program.

ČSSD 1990. Program Československé sociální demokracie schválený XXIV. sjezdem ve dnech 24.-25. března 1990.

ČSSD 1992. Volební program.

ČSSD 1996. Volební program „Lidskost proti sobectví“.

ČSSD 1998. Volební program „Alternativa pro naši zemi“.

ČSSD 2002. Volební program „Člověk na prvním místě““.

ČSSD 2006. Volební program „Jistoty a prosperita“.

ČSSD 2010. Malý volební program.

ČSSD 2010. Oranžová kniha - kultura.

ČSSD 2010. Volební program „Změny a naděje - lepší život pro obyčejné lidi“.

HARNA, Josef, ed. Politické programy českého národního socialismu. Praha: Historický ústav AV ČR, 1998. ISBN 8085268795.

HARNA, Josef a Martin KUČERA, eds. Politické programy českých „pokrokových“ stran 1896-1920. Praha: Historický ústav AV ČR, 2010. ISBN 978-8-7286-174-3.

HARNA, Josef a Vlastislav LACINA, eds. Politické programy českého a slovenského agrárního hnutí 1899-1938. Praha: Historický ústav AV ČR, 2007. ISBN 978-80-7286-113-2.

KATEDRA DĚJIN KSČ A VĚDECKÉHO KOMUNISMU PRO FILOSOFICKOU A PŘÍRODOVĚDECKOU FAKULTU UNIVERSITY J. E. PURKYNĚ. Politický program ČSSD, ČSL, ČSNS, KSČ. Brno, 1970.

KDU-ČSL 1992. Průvodce politikou KDU-ČSL.

KDU-ČSL 1996. Volební program.

KDU-ČSL 1998. Průvodce politikou KDU-ČSL - podrobný volební program.

KDU-ČSL 2006. Volební program „Klidná síla“.

Koalice 2002. Volební program „Rovné šance pro každého“.

KSČ 1990. Volební program.

KSČM 1992. Volební program.

KSČM 1996. Volební program KSČM 1996-2000 „Socialismus - šance pro budoucnost““.

KSČM 1998. Volební program „Jiní o lidech, my s lidmi“.

KSČM 2002. Volební program „S lidmi pro lidi““.

KSČM 2006. Volební program KSČM na období 2006-2010.

KSČM 2010. Otevřený volební program KSČM pro volby do PS PČR 2010.

LSU 1992. Realizační program „Československo sobě“.

MAREK, Pavel, ed. Politické programy českého politického katolicismu 1894-1938. Praha: Historický ústav AV ČR, 2011. ISBN 978-80-7286-192-7.

MERVART, Jan a Dana MUSILOVÁ. Dokumenty $k$ dějinám Komunistické strany Československa. Hradec Králové: Univerzita Hradec Králové, 2006. ISBN 8086845583. 
NÁRODNÍ STRANA. Politický program Národní strany práce, nákladem vlastním, 1925.

ODA 1992. Volební program.

ODA 1996. Volební program.

ODS 1992. Volební program „Svoboda a prosperita“.

ODS 1996. Volební program.

ODS 1998. Volební program „Hlavu vzhůru“.

ODS 2002. Volební program.

ODS 2006. Volební program „Společně pro lepší život““.

ODS 2010. Volební program „Řešení, která pomáhaji““.

OF 1990. Volební program „Přijmout odpovědnost za vlastní budoucnost“.

PROKS̆, Petr, ed. Politické programy Českoslovanské a Československé sociálně demokratické strany dělnické 1878-1948. Praha: Historický ústav AV ČR, 1998. ISBN 8085268884.

SPR-RSČ 1996. Volební program.

SZ 2006. Volební program „Kvalita života“.

ŠŤASTNÝ, Jiří, ed. Sborník dokumentů ke studiu dějin Komunistické strany Československa a mezinárodního komunistického a dělnického hnutí. Praha: Naše vojsko, 1988.

TOP 09 2010. Volební program.

US 1998. Volební program „Nová volba“.

VV 2010. Politický program.

\section{Autoři}

Stanislav Balik je vedoucím Katedry politologie Fakulty sociálních studí Masarykovy univerzity. Odborně se zaměřuje na české církevní dějiny, lokální politiku a nedemokratické režimy. Je autorem sedmi a spoluautorem osmi monografíi (například Katolická církev v Československu 1945-1989, Komunální politika, Letnice 20. století, Miloval jsem okrasu domu Tvého, Postkomunistické nedemokratické režimy), z nichž dvě byly publikovány i v Německu a Polsku, a řady odborných článků zveřejněných v domácích i zahraničních časopisech.

Kontakt: balik@fss.muni.cz

Otto Eibl je odborným asistentem na Katedře politologie Fakulty sociálních studií Masarykovy univerzity. Odborně se zaměřuje zejména na výzkum programatiky politických stran, politický prostor, politickou komunikaci a politický marketing.

Kontakt: eibl@fss.muni.cz 